\title{
Transient Directional Solidification of Cast Iron: Microstructure Formation, Columnar to Equiaxed Transition and Hardness
}

\author{
Thiago Sartorello Spinola ${ }^{a}$, José Eduardo Spinelli ${ }^{a *}$ \\ ${ }^{a}$ Department of Materials Engineering, Federal University of São Carlos - UFSCar, Washington Luis \\ Rd, $k m$ 235, 13565-905, São Carlos, SP, Brazil
}

Received: December 19, 2015; Revised: April 28, 2016; Accepted: May 11, 2016

\begin{abstract}
A number of applications may require cast iron. Engine cylinder blocks, flywheels, gearbox cases, machine-tool bases may be manufactured by using grey cast iron while bearing surfaces with white cast iron. Thus, understanding the solidification behaviour of eutectic cast iron becomes an essential task, with certain points to be accomplished. Transient directional solidification may provide particular advantages in order to deal with these items, such as the large variation of growth rate (V) and cooling rate $(\mathrm{T})$ values, which may allow a variety of microstructures and morphologies to be studied. The aim of this work is to examine the macrostructure regions, scale of the dendritic microstructure, proportions of the formed phases and hardness of samples obtained by transient directional solidification of a eutectic cast iron $(\mathrm{Fe}-3.5 \mathrm{wt} \% \mathrm{C}-2.5 \mathrm{wt} \% \mathrm{Si})$. It was shown that a CET criterion should be based on a critical $\mathrm{V}$ value at the solidification front of about $0.6 \mathrm{~mm} / \mathrm{s}$. The effects of the formed phases, their proportions and $\lambda_{2}$ on hardness of the cast alloy are assessed.
\end{abstract}

Keywords: cast iron, CET, hardness, microstructure, eutectic

\section{Introduction}

Cast iron is a binary iron-carbon of multicomponent Fe$\mathrm{C}-\mathrm{X}$ alloy that is rich in carbon and exhibit a considerable amount of eutectic in the solid state. According to the metastable phase diagram, $\mathrm{Fe}-\mathrm{Fe}_{3} \mathrm{C}$, the white eutectic or austenitic $(\gamma)$, iron carbide $\mathrm{Fe}_{3} \mathrm{C}$ may form. Considering the stable diagram iron-graphite (a significant amount of $\mathrm{Si}$ is required in this case), the gray eutectic, austenite-graphite (Gr) may grow. According to Polackzek and Santos ${ }^{1}$ a number of graphite shapes can solidify as part of the austenitegraphite eutectic as follows: flake (plate) graphite (FG), compacted (vermicular) graphite (CG), coral graphite and spheroidal (nodular) graphite (SG). The type of morphology obtained depends basically on the chemical composition, the temperature gradient/growth rate ratio $(\mathrm{G} / \mathrm{V})$ and the cooling rate $(\dot{\mathrm{T}})$. Depending on the equivalent carbon, the primary phase can be either austenite for hypoeutectic cast iron or graphite for hypereutectic cast iron. The literature is scarce on studies stressing to the formation and growth characteristics of austenite dendrites. More attention from investigators has been given to the eutectic cell count and morphology. This is probably because dendrites are not readily discernible in the structure. On the other hand, a lot of research have been done on the relationships between dendritic growth and the solidification thermal parameters (G, V and T) for light alloys ${ }^{2-5}$.

The usual $\lambda^{2} \mathrm{~V}=$ constant relation of regular eutectics proposed by Jackson and Hunt $(\mathrm{J}-\mathrm{H})^{1,6}$ may not be obeyed during the growth of austenite-flake graphite eutectic. Different experiments proposed other exponents to be adopted instead $-1 / 2$. The following $\lambda-V$ relationships in flake graphite cast

*e-mail: spinelli@ufscar.br iron were cited in ref $7: \lambda=3.8 \times 10^{-5} \mathrm{~V}^{-0.5} \mathrm{~cm}$ (experimental); $\lambda=0.56 \times 10^{-5} \mathrm{~V}^{-0.78} \mathrm{~cm}$ (experimental); $\lambda=7.1 \times 10^{-5} \mathrm{~V}^{-0.57} \mathrm{~cm}$ (experimental) and $\lambda=1.15 \times 10^{-5} \mathrm{~V}^{-0.5} \mathrm{~cm}$ (theoretical- $\mathrm{JH}$ ). There is a limitation on these values since growth rates are generally lower than $10^{-2} \mathrm{~mm} / \mathrm{s}$ due to the imposed stationary conditions. Further, there is no agreement in literature concerning the mentioned relationships. Furthermore, data on spacing of the ledeburite eutectic (austenitic $(\gamma)$, iron carbide $\mathrm{Fe}_{3} \mathrm{C}$ ) for low solidification velocities showed that the model $\lambda^{2} \mathrm{~V}$ does not fit the experimental scatter ${ }^{8}$.

It is well known that cooling rate has a significant influence on the morphology of the $\gamma-\mathrm{Fe}_{3} \mathrm{C}$ eutectic. At moderate undercoolings, ledeburite structure is expected. High cooling rates, as obtained in quenching experiments, produce a degenerate eutectic structure dominated by $\mathrm{Fe}_{3} \mathrm{C}$ plates $^{1}$. According to Park and Verhoeven ${ }^{8}$ the primary effect of $\mathrm{Si}$ addition on the $\gamma-\mathrm{Fe}_{3} \mathrm{C}$ structure of ledeburite is to cause the formation of cells and dendrites. Both cells and dendrites of eutectic through alloys form with plate-shaped cross sections. Because of the generated supercooling, the first stage in the white iron formation was the growth of $\mathrm{Fe}_{3} \mathrm{C}$ plate dendrites, just as in hypereutectic alloys. Only in the hypoeutectic alloys, the $\mathrm{Fe}_{3} \mathrm{C}$ dendrites grow around the pre-existing austenite dendrites. Then, in the second stage for both hyper- and hypoeutectic alloys, a cooperative eutectic growth of austenite and $\mathrm{Fe}_{3} \mathrm{C}$ occurs on the sides of the primary $\mathrm{Fe}_{3} \mathrm{C}$ plates as the liquid between the plates solidifies.

According to Jacot et al. ${ }^{9}$, the gray and white iron eutectic can exhibit either a fully columnar morphology or an entirely equiaxed structure. This would be correlated with the solidification conditions. Often, both morphologies are observed in the casting, resulting in a transition from 
an outer columnar zone to a central equiaxed region. Jacot and co-authors ${ }^{9}$ observed that the mechanisms associated with the microstructural transition may be predicted by their model. Further, the columnar front of white iron was stopped or broken up by equiaxed grains of gray iron.

As established by Svidró and Diószegi ${ }^{10}$ shrinkage defect is able to be formed in connection with the dendrite coherency. Even though a number of studies have been performed on columnar-to-equiaxed transition (CET), it remains unclear the exact mechanism of shrinkage porosity formation. After filling molten alloy in the mold, dendrites start growing from the mold surface into the melt all-around the mold wall creating a container shaped columnar zone. Inside the melt, nucleation of the equiaxed grains starts on heterogeneous nucleation sites. The moment when the equiaxed and columnar grains fill up the volume is called dendrite coherency or the columnar to equiaxed transition (CET). Shrinkage porosity in lamellar cast iron is most likely to form in connection to the dendrite coherency ${ }^{11}$. Svidró and Diószegi ${ }^{10}$ stated that there are limited known investigation methods to determine CET in cast iron and consequently there is no information on how metallurgical parameters are affecting its occurrence. Investigations on vertically upward directional solidification of $\mathrm{Al}-\mathrm{Cu}, \mathrm{Al}-\mathrm{Si}$ and $\mathrm{Sn}-\mathrm{Pb}$ alloys have proposed a CET criteria based on critical cooling rates of about $0.2 \mathrm{~K} / \mathrm{s}, 0.17 \mathrm{~K} / \mathrm{s}$ and $0.014 \mathrm{~K} / \mathrm{s}$, respectively, with the columnar growth prevailing throughout the casting for cooling rates higher than these critical values ${ }^{12-14}$. The application of such criterion based on a critical solidification thermal parameter has never been verified considering data from solidification of cast iron.

The scope of this paper is to comprehend the microstructure formation of a directionally solidified cast iron under transient heat flow conditions. The primary and eutectic dendrites are examined and characterized by the secondary dendritic arm spacing, $\lambda_{2}$, and its dependence on the growth rate $(V)$. Experimental correlations between hardness and $\lambda_{2}$ and between hardness and the proportion of phases and constituents are envisaged along the length of the casting. Finally, experimental CET data under different solidification conditions are examined with a view to determine if the CET for cast iron occurs at a critical solidification thermal parameter.

\section{Experimental procedure}

A directional solidification setup was used so that heat was directionally extracted only through a water-cooled bottom. In order to vary the metal/mold interface conditions, either low carbon steel or graphite bottom parts were used so that the effects of mold material could be noted. Graphite was chosen since it is used as die material under water-cooled regime during industrial continuous casting of cast iron, making possible the production of bars with fine-grained as cast structure. Details about the solidification system and the mold used in the present investigation can be seen in Figure 1. The cast iron was melted in an induction furnace until molten reached a predetermined temperature. After that, molten alloy was poured into the mold with water supply already initiated. Three experiments were carried out according

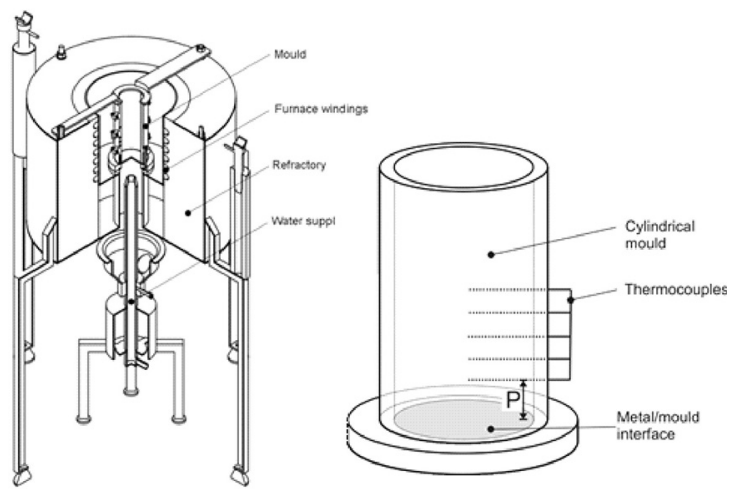

Figure 1: Schematic vertical upward directional solidification casting assembly and mold details (right side).

with different solidification conditions for CET analysis as follows: $\mathrm{G} 1$ : bottom part of the mold in graphite; $\Delta \mathrm{T} \sim 40 \mathrm{~K}$; $\mathrm{S} 1$ : bottom part of the mold in low carbon steel; $\Delta \mathrm{T} \sim 80 \mathrm{~K}$ and S2: bottom part of the mold in low carbon steel; $\Delta \mathrm{T}=160 \mathrm{~K}$. $\Delta \mathrm{T}$ is the maximum melt superheating level above eutectic temperature acquired by the first thermocouple closer to the cooled surface of the casting.

Continuous temperature measurements in the casting were performed during solidification by fine type $\mathrm{K}$ thermocouples $(0.2 \mathrm{~mm}$ diameter wire sheathed in $1.0 \mathrm{~mm}$ outside diameter stainless steel tubes) placed along the castings length.

The Nital's reagent $(98 \mathrm{ml}$ of ethanol and $2 \mathrm{ml}$ of $\mathrm{HNO}_{3}$ ) and etching times of $2 \mathrm{~min}$ and $5 \mathrm{~s}$ were used to reveal the macrostructures and the microstructures, respectively. The CET, if any, was measured along a vertical central section and from the bottom of the casting. The intercept method was adopted on longitudinal samples from the experiment G1 in order to determine the secondary dendrite arm spacing $\left(\lambda_{2}\right)^{15}$. Image processing systems were used to measure the cited spacings and their distribution ranges. At least 30 measurements were performed for each selected position along the first $20 \mathrm{~mm}$ of the castings length, region where features of white cast iron were detected.

Area fractions of $\mathrm{Fe}_{3} \mathrm{C}$ carbides, graphite and pearlite were determined by counting the relative areas proportions of each phase/constituent using image processing software (Image J). At least 10 images were examined to yield the average value corresponding to each phase/constituent on each position to be considered.

The samples used for segregation analysis were extracted from different positions along the length of the DS casting from the G1 experiment. Such analyzes were performed by optical emission spectrometry, applying electrical energy in the form of spark. So, estimate local average $\mathrm{Si}$ and $\mathrm{C}$ concentrations through a certain probe area could be established for each position. Hardness measurements were carried out using a Brinell hardness tester, applying a steel ball of $2.5 \mathrm{~mm}$ diameter and a load of $187.5 \mathrm{kgf}$ for $30 \mathrm{~s}$. The adopted hardness value of a representative 
position was the average of at least 10 measurements on each cast iron sample.

\section{Results and discussion}

The evolution of temperature along the casting length, as a function of time, was acquired during growth of the aforementioned G1, S1 and S2 experiments, as shown in Figure 2. The experimental cooling curves refer to thermocouples located at specific distances from the cooled surface. The thermal readings have been used to provide a plot of position from the metal/mold interface and the corresponding time of the eutectic front passing by each thermocouple. The derivative of this function with respect to time gave values for the growth rate (V), as shown in Figure 3a. The experimental tip cooling rate $(\dot{\mathrm{T}})$ along the casting length is shown in Figure $3 \mathrm{~b}$. The experimental tendencies inserted in Figure 3 demonstrate that a large range of cooling rate was obtained while a smaller range of growth rate values can be seen. The reason why the eutectic front displaced faster in the case of bottom part in steel is probably due to the higher thermal conductivity of this material compared with graphite. Thus, higher growth rates can be observed concerning the solidification of cast iron against low carbon steel bottom part of the mold ${ }^{16}$. Similarly, experimental cooling rates obtained during the experiments adopting low carbon steel (S1, S2) were higher than those associated with G1 experiment.

The resultant directionally solidified macrostructures are shown in Figure 4. Despite transitions being located very close to the bottom of the casting, the basic feature of the CET shown by these macrostructures is that the transition is sharp. Very fine columnar grains may be observed with no presence of entrapped equiaxed grains. The CET is dependent on solidification thermal parameters which vary with time and position during transient solidification. In order to determine more accurately these parameters regarding the position of the CET more thermocouples were positioned near the cooled surface of the casting than in the farther positions. Thus, more accurate interpolations are provided.

The resultant solidification thermal parameters associated with the CET transition (V and $\dot{\mathrm{T}}$ ) have been experimentally determined as can be seen in Table 1. According to this list in table 1, it seems that cooling rate is not sensitive to the position of the CET. On the other hand, the response of

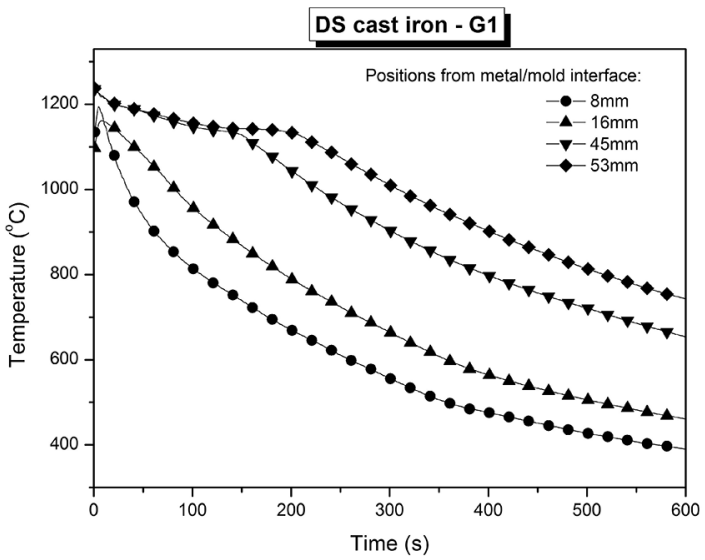

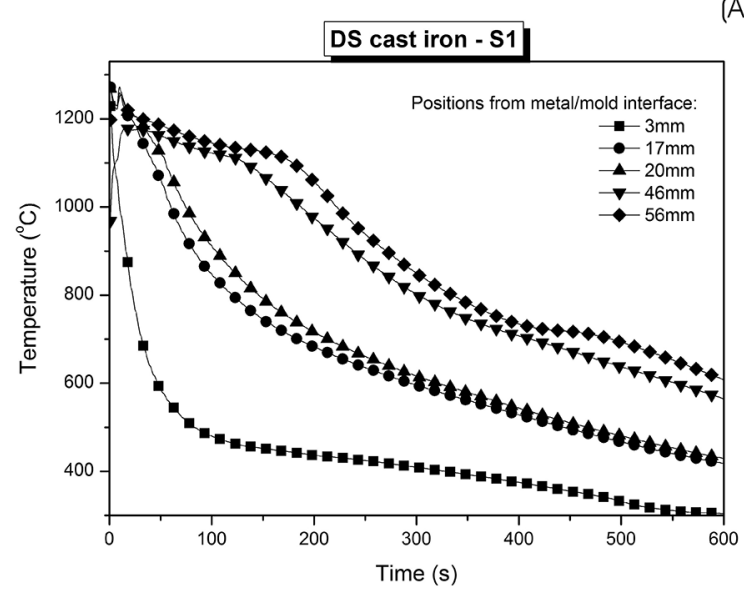

(B)

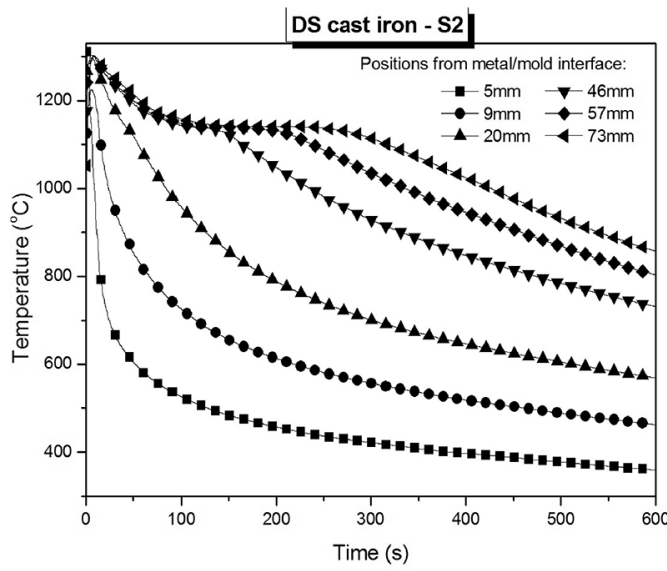

(C)

Figure 2: Experimental cooling curves obtained for different positions along the length of the DS cast iron castings: (a) G1: bottom part of the mold in graphite; $\Delta \mathrm{T} \sim 40 \mathrm{~K}$; (b) S1: bottom part of the mold in low carbon steel; $\Delta \mathrm{T} \sim 80 \mathrm{~K}$ and (c) S2: bottom part of the mold in low carbon steel; $\Delta \mathrm{T}=160 \mathrm{~K} . \Delta \mathrm{T}$ is the maximum melt superheating level above eutectic temperature acquired by the first thermocouple near the cooled surface of the casting. 


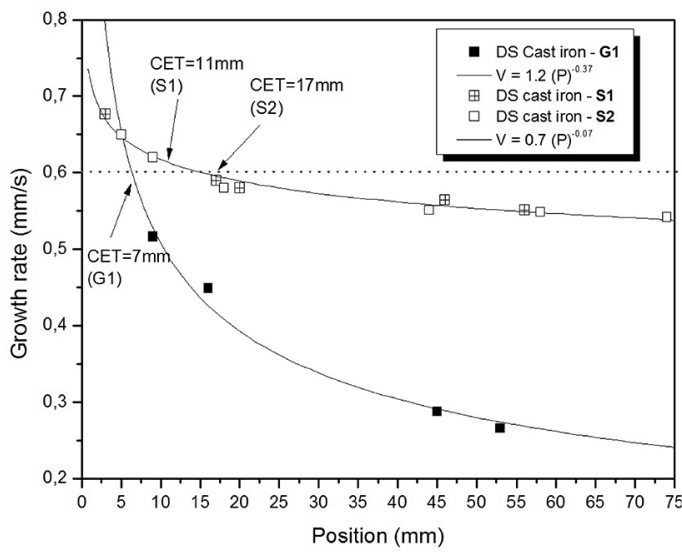

(a)

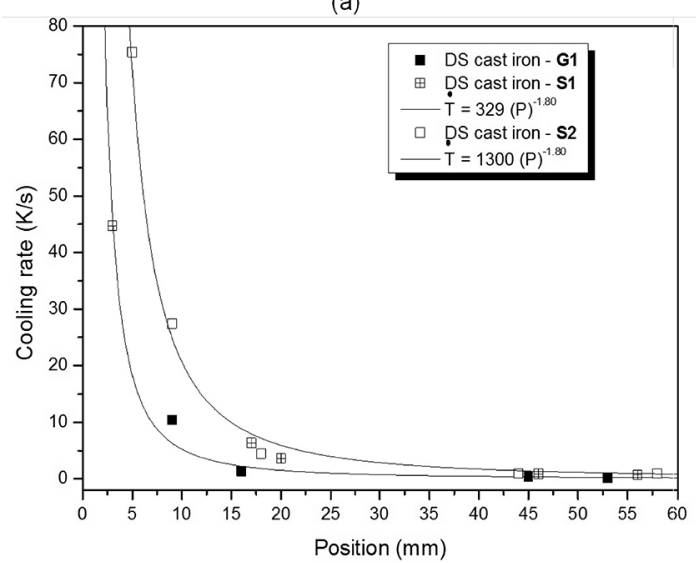

(b)

Figure 3: (a) Growth rate and (b) Cooling rate as a function of position from the cooled surface of the DS cast iron.

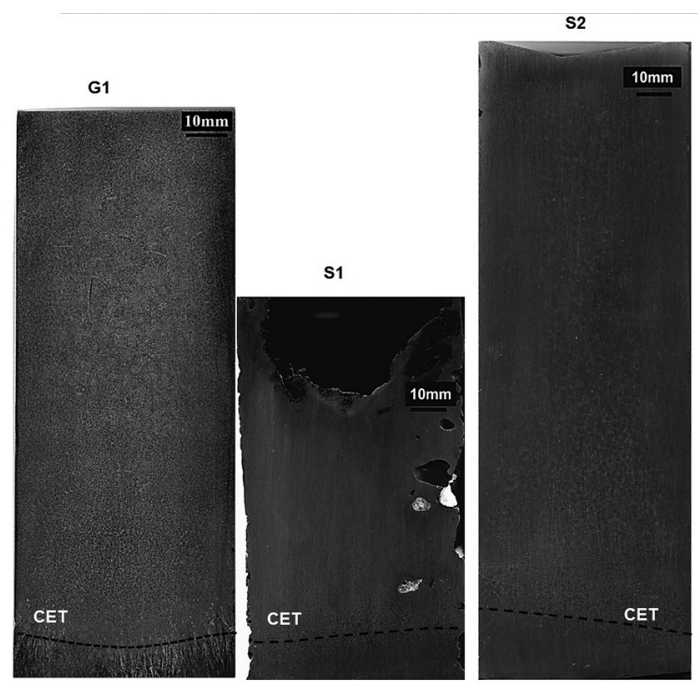

Figure 4: Longitudinal macrostructures of the DS cast iron for the three examined solidification conditions.

growth rate values against CET is quite different from that of cooling rate, with very similar values of $\mathrm{V}$ found for the different CET positions in the three experiments performed with cast iron.
Table 1: CET positions and solidification thermal parameters for the tested directionally solidified cast iron conditions.

\begin{tabular}{lccc}
\hline Experiment & CET $(\mathrm{mm})$ & $\mathrm{V}(\mathrm{mm} / \mathrm{s})$ & $\mathrm{T}(\mathrm{K} / \mathrm{s})$ \\
\hline G1 & 7.0 & 0.58 & 9.9 \\
S1 & 11.0 & 0.61 & 4.4 \\
S2 & 17.0 & 0.59 & 7.9 \\
Average & & 0.59 & 7.40 \\
\hline
\end{tabular}

The thermal CET criteria are recognized as very good indicative for the macrostructural transition as reported in several articles ${ }^{12-14,17,18}$. However, none previous study has been found on determining the solidification thermal parameters associated with the CET of cast iron. In the case of Sn-based ${ }^{12,13,19}$ and Al-based ${ }^{14,17,18}$ alloys investigations have been addressed to single-phase and hypoeutectic alloys. In these cases, critical cooling rate was established as a realistic criterion, since cooling rate $(\dot{\mathrm{T}})$ encompasses growth rate (V) and temperature gradient $(\mathrm{G})$, i.e., $=\mathrm{G} \times \mathrm{v}$. The present investigation deals with a eutectic alloy and in this case it appears that a critical growth rate of about $0.6 \mathrm{~mm} / \mathrm{s}$ is adequate criteria for cast iron. This CET criterion for cast iron does not depend on either mold material or superheat.

Typical microstructures of the G1 experiment were chosen along the directionally solidified cast iron with a view to represent not only the scale of the microstructure but also the different formed phases and morphologies. Such optical microstructures are depicted in Figure 5. A dendritic array is observed in the first three positions $(\mathrm{P})$ closer to the cooled surface of the casting, i.e., $\mathrm{P}=4 \mathrm{~mm}, \mathrm{P}=9 \mathrm{~mm}$ and $\mathrm{P}=14 \mathrm{~mm}$, which are associated with cooling rate values of 27.1, 6.3 and $2.8 \mathrm{~K} / \mathrm{s}$, respectively. Two ranges of dendritic array sizes may be observed. It appears that coarser dendrites (yellow rectangle) refer to the growth of austenite phase while finer structures (red rectangle) are dendrites of eutectic, which grow around the pre-existing austenite dendrites ${ }^{8}$. The presence of $\mathrm{Fe}_{3} \mathrm{C}$ carbides is observed up to $20 \mathrm{~mm}$ from the bottom of the casting. Entrapped graphite (white arrow) may be observed for $\mathrm{P}=9 \mathrm{~mm}$. As cooling rate diminishes, nucleation and growth of graphite start to prevail with a typical FG cast iron microstructure being seen for the $\mathrm{P}=30 \mathrm{~mm}$, featured by graphite plates distributed within a pearlitic matrix. Larger graphite flakes have grown for farther positions as in the case of $\mathrm{P}=50 \mathrm{~mm}$, which is due to slow cooling conditions, i.e., $=0.3 \mathrm{~K} / \mathrm{s}$.

Two experimental laws are adopted to represent the evolutions of the $\lambda_{2}$ with $\mathrm{v}$ as shown in Figure 6 . The exponent $-1 / 2$ recommended by Jackson and Hunt ${ }^{6}$ encompasses the dendritic growth of eutectic while the exponent -1.0 represents the austenite dendritic growth. The ranges of spacing sizes were from 11.0 to $28.0 \mu \mathrm{m}$ and from 3.5 to $5.5 \mu \mathrm{m}$ for austenite and $\mathrm{Fe}_{3} \mathrm{C}$ dendrites, respectively. The experimental laws $\lambda_{2}=3.1 \times(\mathrm{V})^{-1 / 2} / \lambda_{2}=6.3 \times(\dot{\mathrm{T}})^{-1 / 4}$ (eutectic) and $\lambda_{2}=9.4 \times(\mathrm{V})^{-1.0} / \lambda_{2}=46.5 \times(\mathrm{T})^{-1 / 2}$ (primary growth) are able to represent the evolutions of the microstructural spacings for white cast iron.

Figure 7 shows the experimental macrosegregation profiles of $\mathrm{C}$ and $\mathrm{Si}$ along the length of the directionally solidified cast iron. It can be seen that regions closer to the top of the casting have lower silicon ( $\mathrm{Si}$ ) contents, while for positions closer to the casting cooled surface the concentration is higher. The $\mathrm{Si}$ 


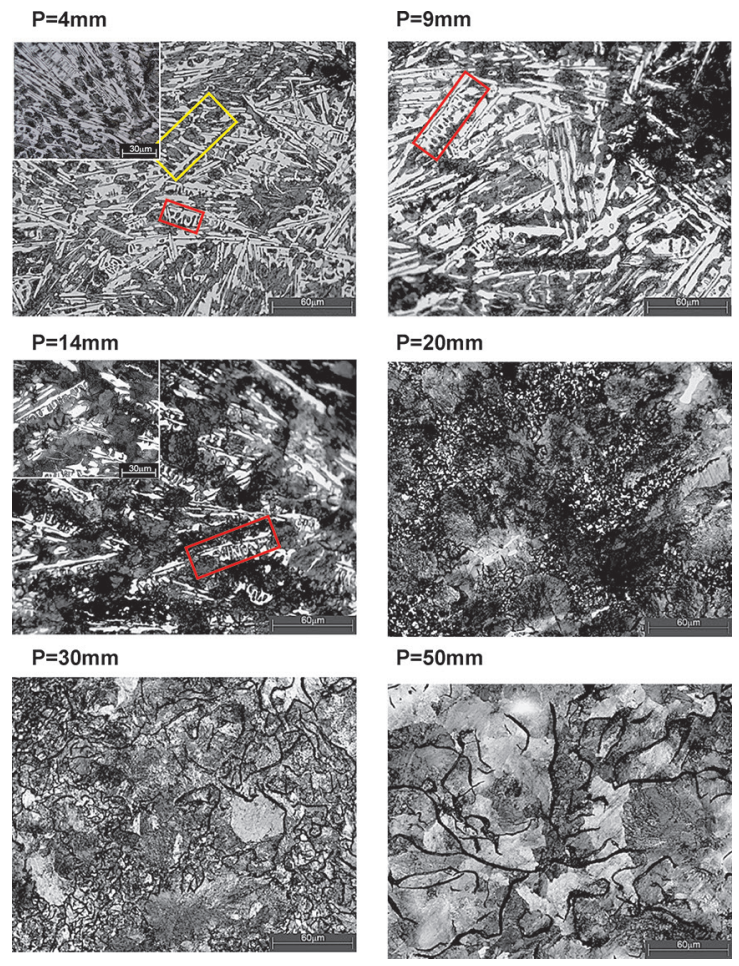

Figure 5: Typical microstructures of the directionally solidified cast iron from a number of different positions $(\mathrm{P})$ along the length of the casting. $\mathrm{P}$ is the position from metal/mold interface. The inset images emphasize the occurrence of the eutectic dendrites.

macrosegregation profile has the typical trend of a positive segregation distribution for a solute redistribution coefficient $\left(\mathrm{k}_{0}\right)$ higher than unity ${ }^{20}$. This means that iron (solvent) is rejected with the progress of solidification. In contrast, a normal macrosegregation profile is observed for the carbon (C). Since austenite is enriched in $\mathrm{Si}, \mathrm{C}$ segregation depends on $\mathrm{Si}$ presence. Si probably decreases solubility of $\mathrm{C}$ in $\mathrm{Fe}$, which stimulates $\mathrm{C}$ to be rejected to the liquid immediately ahead of the solidification front. In spite of the higher silicon content and lower $\mathrm{C}$ content of the positions closer to the bottom of casting $(\mathrm{P}<20 \mathrm{~mm})$, a predominance of white cast iron (see top microstructures in Figure 5) is guaranteed by the higher cooling rates at these regions.

Figure 8 shows the prevalence of phases as a function of the cooling rate level experienced by the DS cast iron. Due to the formation of white cast iron closer to the casting cooled surface, a considerable amount of $\mathrm{Fe}_{3} \mathrm{C}$ carbides is observed for cooling rates higher than $1.5 \mathrm{~K} / \mathrm{s}$. For lower cooling rates $(<1.5 \mathrm{~K} / \mathrm{s})$, graphite and pearlite start to prevail with rather increase in proportions with slower cooling condition. Brinell harness values were inserted inside the graph so that contributions of the formed phases and their proportions on hardness are highlighted.

While Hall-Petch type formulae $\left(\mathrm{HB}_{\mathrm{x}}=\mathrm{HB}_{0}+\mathrm{k}_{\mathrm{e}} \lambda_{2}{ }^{-1 / 2}\right)$ have been proposed to relate hardness and the microstructural scale of Al-Fe and $\mathrm{Zn}-\mathrm{Cu}$ alloys ${ }^{21,22}$, relations like that were not found in literature of cast iron. Hence, the effect of $\lambda_{2}$ on Brinell hardness of the cast iron can be seen in Figure 9 through the purpose of a Hall-Petch fitting with the present experimental scatter. It seems to be appropriate. This $\lambda_{2}$ value is the average

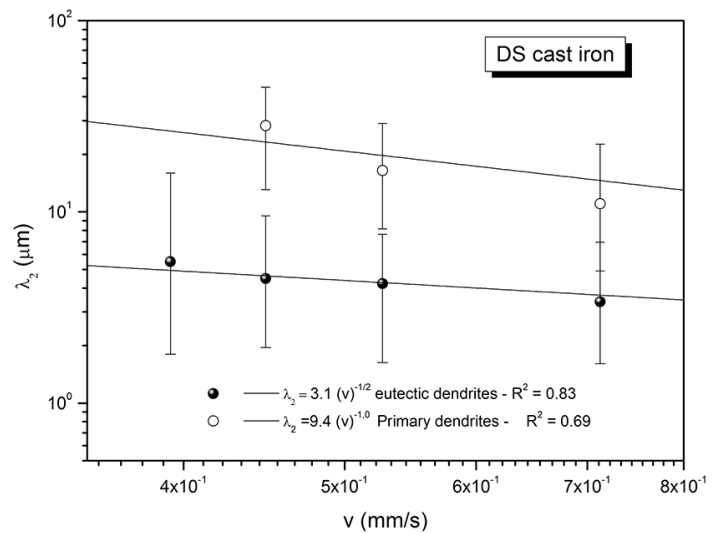

(A)

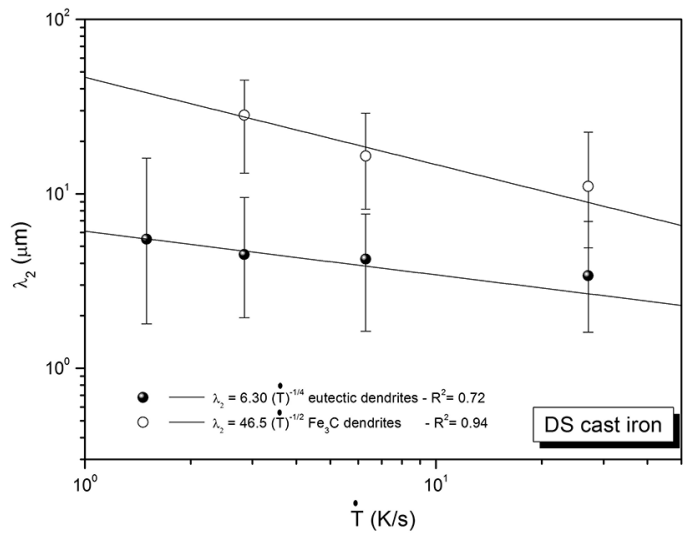

(B)

Figure 6: Primary and eutectic secondary dendritic spacing $\left(\lambda_{2}\right)$ as a function of (a) growth rate and (b) cooling rate for the directionally solidified cast iron. $\mathrm{R}^{2}$ is the coefficient of determination.

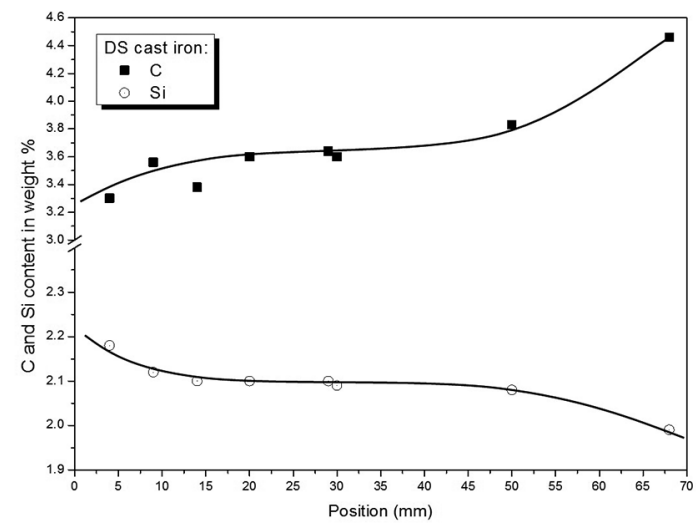

Figure 7: Carbon $(\mathrm{C})$ and silicon (Si) profiles along the length of the DS casting.

between coarse and fine spacing. Although hardness is shown to increase with the decrease in $\lambda_{2}$, the contributions of the phases and their proportions may not be neglected. For instance, for hardness of $512 \mathrm{HB}$ the associated fraction of the hard $\mathrm{Fe}_{3} \mathrm{C}$ carbide is $45 \%$ with $\lambda_{2}$ of $7 \mu \mathrm{m}$ while for $316 \mathrm{HB}$ around $20 \%$ of carbide in fraction is observed with $\lambda_{2}$ of $16 \mu \mathrm{m}$. Lower $\lambda_{2}$ 


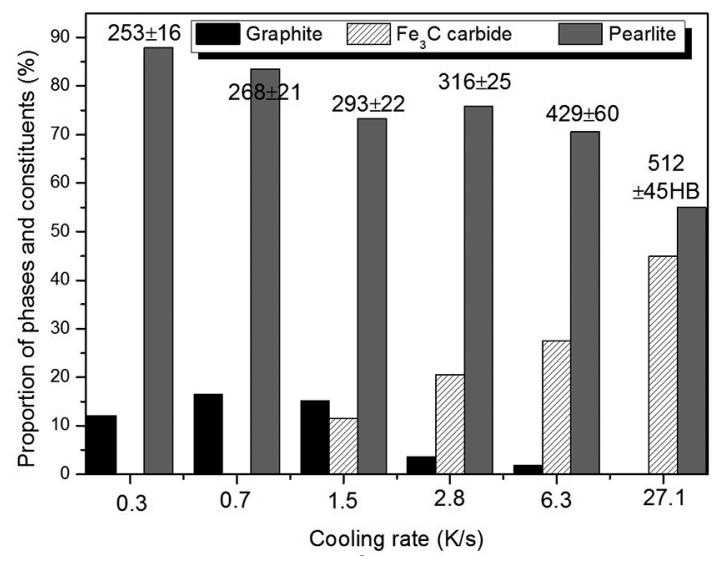

Figure 8: Cooling rate and hardness (HB) experimental relations with the proportions of phases and constituents in the directionally solidified cast iron.

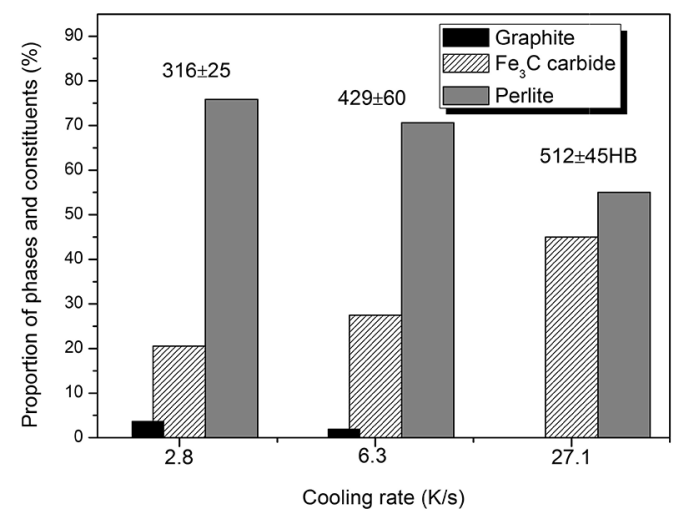

(A)

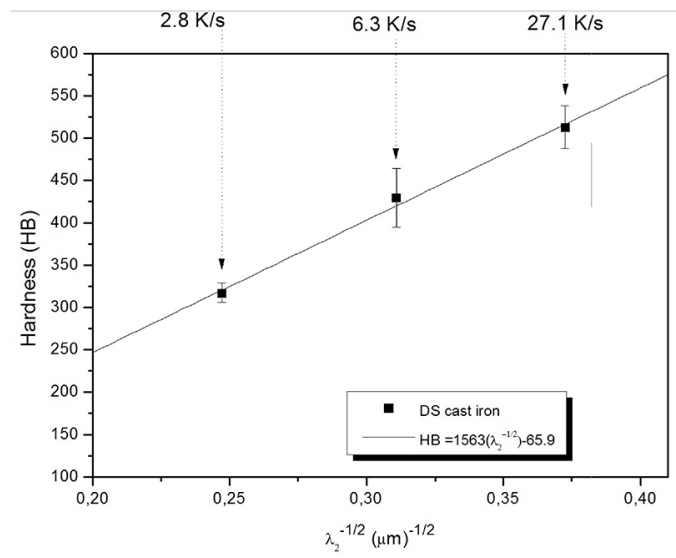

(B)

Figure 9: Effects of magnitude of average $\lambda^{2}$ on Brinell hardness along the length of the DS cast iron. The fractions of phases vs. cooling rate complete de analysis.

is responsible for better distribution of the harder $\mathrm{Fe}_{3} \mathrm{C}$ phase. The combined effects of these features cooperate with the final hardness evolution obtained in DS cast iron.

\section{Conclusions}

The following can be drawn from the present experimental study:

- It was shown that a criterion for CET of cast iron (Fe-3.5wt $\% \mathrm{C}-2.5 \mathrm{wt} \% \mathrm{Si}$ ) should be based on a critical growth rate of about $0.6 \mathrm{~mm} / \mathrm{s}$, which maintains realistic for a variety of superheats and materials of the mold.

- Experimental growth laws were proposed relating the finer and coarser secondary dendrite arm spacings of the cast iron with the experimental thermal parameters $\mathrm{v}$ and $\mathrm{T}$. Power functions having $-1 / 2 /-1 / 4$ and $-1.0 /-1 / 2$ exponents were shown to represent the evolutions of the eutectic and austenite dendrites, respectively.

- A Hall-Petch type equation has been proposed relating hardness (HB) to $\lambda_{2}$ : the smaller $\lambda_{2}$, the higher HB. The hardness was shown to increase significantly with the combined increase in the area fraction of the $\mathrm{Fe}_{3} \mathrm{C}$ carbide and decrease in $\lambda_{2}$.

\section{Acknowledgements}

The authors acknowledge the financial support provided by FAPESP (The Scientific Research Foundation of the State of São Paulo, Brazil) and CNPq (The Brazilian Research Council). In addition, we would like to thank engineer Anderson José Tomaz, from the Department of Products and Process Engineering at Tupy S.A - Mauá, São Paulo, Brazil for providing chemical analysis results.

\section{References}

1. Polackzek AB, Santos D. Solidification of eutectic alloys - cast iron. In: ASM Handbook, volume 15: Casting. Materials Park: ASM International: 2008. p.317-329.

2. Verma A, Kumar S, Grant PS, O'Reilly KAQ. Influence of cooling rate on the Fe intermetallic formation in an AA6063 Al alloy. Journal of Alloys and Compounds. 2013;555:274-282.

3. Fei WD, Kang SB. Effects of cooling rate on solidification process in Al-Mg-Si alloy. Journal of Materials Science Letters. 1995;14(24):1795-1797.

4. Quaresma JMV, Santos CA, Garcia A. Correlation between unsteady-state solidification conditions, dendrite spacings, and mechanical properties of Al-Cu alloys. Metallurgical and Materials Transactions A. 2000;31(12):3167-3178.

5. Goulart PR, Spinelli JE, Osório WR, Garcia A. Mechanical properties as a function of microstructure and solidification thermal variables of Al-Si castings. Materials Science and Engineering: A. 2006;421(1-2):245-253.

6. Jackson KA, Hunt JD. Lamellar and rod eutectic growth. Transactions of the Metallurgical Society of AIME. 1966;236:1129-1142.

7. Minkoff I. The Physical Metallurgy of Cast Iron. New Jersey: John Wiley \& Sons; 1983. 318p.

8. Park JS, Verhoeven JD. Directional solidification of white cast iron. Metallurgical and Materials Transactions A. 1996;27(8):2328-2337. 
9. Jacot A, Maijer D, Cockcroft SL. A two-dimensional model for the description of the columnar-to-equiaxed transition in competing gray and white iron eutectics and its application to calender rolls. Metallurgical and Materials Transactions A. 2000;31(8):2059-2068

10. Svidró P, Diószegi A. Determination of the columnar to equiaxed transition in hypoeutectic lamellar cast iron. Transactions of the Iron and Steel Institute of Japan. 2014;54(2):460-465.

11. Elmquist L, Diószegi A. Shrinkage porosity and its relation to solidification structure of grey cast iron parts. International Journal of Cast Metal Research. 2010;23(1):44-50.

12. Siqueira CA, Cheung N, Garcia A. The columnar to equiaxed transition during solidification of $\mathrm{Sn}-\mathrm{Pb}$ alloys. Journal of Alloys and Compounds. 2003;351(1-2):126-134.

13. Siqueira CA, Cheung N, Garcia A. Solidification thermal parameters affecting the columnar-to-equiaxed transition. Metallurgical and Materials Transactions A. 2002;33(7):2107-2118.

14. Peres MD, Siqueira CA, Garcia A. Macrostructural and microstructural development in Al-Si alloys directionally solidified under unsteady-state conditions. Journal of Alloys and Compounds. 2004;381(1-2):168-181.

15. Gündüz M, Çadirli E. Directional solidification of aluminiumcopper alloys. Materials Science and Engineering: A. 2002;327(2):167-185.
16. MATWEB. Materials Properties Data, Graphite, Carbon, $C$ and AISI 1020 Steel, cold rolled. Available from: $<\mathrm{http}: / / \mathrm{www}$. matweb.com>. Access in: 02/02/2015.

17. Gomes CHU, Kikuchi RHL, Barros AS, Silva JNS, Silva MAPS, Moreira ALS, et al. On the Natural Convection in the Columnar to Equiaxed Transition in Directionally Solidified Aluminumbased Binary and Multicomponent Alloys. Materials Research 2015;18(6):1362-1371.

18. Rocha OL, Gomes LG, Moutinho DJC, Ferreira IL, Garcia A. The columnar to equiaxed transition in the directional solidification of aluminum based multicomponent alloys. REM: Revista Escola de Minas. 2015;68(1):85-90.

19. Spinelli JE, Ferreira IL, Garcia A. Influence of melt convection on the columnar to equiaxed transition and microstructure of downward unsteady-state directionally solidified $\mathrm{Sn}-\mathrm{Pb}$ alloys. Journal of Alloys and Compounds. 2004;384(1-2):217-226.

20. Jiyang Z. Colour Metallography of Cast Iron. China Foundry. 2010;7(4):470-478.

21. Silva BL, Garcia A, Spinelli JE. The effects of microstructure and intermetallic phases of directionally solidified Al-Fe alloys on microhardness. Materials Letters. 2012;89:291-295.

22. Brito C, Siqueira CA, Spinelli JE, Garcia A. Effects of cell morphology and macrosegregation of directionally solidified $\mathrm{Zn}$-rich $\mathrm{Zn}-\mathrm{Cu}$ alloys on the resulting microhardness. Materials Letters. 2012;80:106-109. 